International Journal of Economics, Business and Accounting Research (IJEBAR)

Peer Reviewed - International Journal

Vol-4, Issue-3, 2020 (IJEBAR)

E-ISSN: 2614-1280 P-ISSN 2622-4771

https://jurnal.stie-aas.ac.id/index.php/IJEBAR

\title{
ENTREPRENEURSHIP DEVELOPMENT FOR STUDENTS
}

\author{
${ }^{1}$ Indra Hastuti, ${ }^{2}$ Indah Wahyu Utami, ${ }^{3}$ Sopingi \\ ${ }^{1}$ Information System Study Program, ${ }^{2}$ Informatics Engineering Study Program, \\ ${ }^{3}$ Information System Study Program \\ University of Duta Bangsa Surakarta \\ Email:_indra_hastuti@udb.ac.id,indah_wahyu@udb.ac.id, sopingi@udb.ac.id
}

\begin{abstract}
:
The development of proper entrepreneurship for students in order to produce independent and sustainable entrepreneurs is needed because there are many ideas and creativity of students to open a business, but they stop at the last activity of lectures, namely the entrepreneurship bazaar. Problems with limited manpower, timely service, marketing and place of business make their business unsustainable. The purpose of this activity is to develop entrepreneurial programs run by students who are profitable and can create jobs and assist the government in alleviating unemployment and poverty. The result of this Entrepreneurship Development Program activity is that 20 student tenants have been formed.
\end{abstract}

Keywords: $\quad$ Development, entrepreneurship, independent business

\section{Introduction}

Organizing entrepreneurship and business-based education in order to prepare independent, innovative, visionary, faithful and globally oriented Human Resources is needed; the importance of entrepreneurship education and training in a campus environment is expected to grow alumni as young entrepreneurs who are able to create jobs. 1) The role of higher education institutions in integrating entrepreneurship education into the curriculum, shaping the character of entrepreneurial independence and implementing entrepreneurship education in the campus environment, 2) The problem in higher education in general in realizing students who are oriented as entrepreneurs is in determining the right entrepreneurial training and development model for students so that they can produce young, independent and sustainable entrepreneurs. Students have a lot of ideas and creativity in opening a business, but they only stop at the end of the lecture, which is usually an entrepreneurship bazaar, after graduating from their entrepreneurship course they stop opening a business.

The problem in the marketing sector is that there is no marketing network with the business world and the industrial world. They do not have a place of business. The purpose of the Student Entrepreneurship Development Program is to develop student entrepreneurship in order to produce new, profitable young entrepreneurs to create jobs and assist the government in alleviating unemployment and poverty. The solution to the problem in determining the right entrepreneurial training and development model is to provide entrepreneurship training to students by applying an entrepreneurial training 
International Journal of Economics, Business and Accounting Research (IJEBAR)

Peer Reviewed - International Journal

Vol-4, Issue-3, 2020 (IJEBAR)

E-ISSN: 2614-1280 P-ISSN 2622-4771

https://jurnal.stie-aas.ac.id/index.php/IJEBAR

development model through a Project Based Learning approach based on contextual business problems, applying the planned business in a real way. This model will be a form of community-based education (fostering active student participation in education and training) which is able to change the mindset of students to have an entrepreneurial spirit and form new entrepreneurs who are profit-oriented and sustainable in business, placing students to carry out apprenticeships at companies or business units. 3) Solution to problems in the field of on-line, off-line and place of business marketing, by providing training for business startups and marketplaces for their products and services. For business premises, we direct us to open a business from our respective homes, as well as providing a place of business on campus.

\section{Method}

a. Disseminating the Entrepreneurship Development program (PPK) to students of the Faculty of Computer Science at Duta Bangsa University (UDB)

b. Recruitment of 20 tenants from PPK participants through selection of business plan proposals and presentations on business plans and business activities they have carried out. The presentation was made online because during the recruitment process during the corona virus pandemic, 19 students were not allowed to come to campus.

The track record of the business that has been carried out, reports on services that have been performed and paying attention to the innovation and creativity products produced, paying attention to the economic value and market needs of the product or being sold make a consideration for recruiting as a tenant.

c. Providing entrepreneurship training, starting with business group mapping, business motivation, industry visits according to business mapping, production practices, packaging of products or services to consumers, on-line and off-line marketing strategies as well as business management and preparation of financial reports.

d. Creating a teaching factor or outlet in the UDB campus environment, monitoring business nets by coming directly to the place of business to find out consumers who come to the outlet and business continuity.

e. Evaluation of PPK activities by evaluating the number of tenants who are truly independent and able to be released to open businesses outside campus.

\section{Result}

\subsection{The Activities Implementation}

Preliminary activities were carried out in early August 2019 by going through a situation and problem analysis. While, for the implementation of activities for 8 months starting in February 2020 at Duta Bangsa University, Surakarta. This activity was attended by students of the Faculty of Computer Science, Duta Bangsa University Surakarta through a program of socialization and tenant selection. From the selection results obtained 20 Student Tenants.

We do PPK activities according to the implementation method with the Project Based Learning (PBL) method. The majority of student businesses are carried out at home using the on-line marketing method and all are done by themselves so that the 
International Journal of Economics, Business and Accounting Research (IJEBAR)

Peer Reviewed - International Journal

Vol-4, Issue-3, 2020 (IJEBAR)

E-ISSN: 2614-1280 P-ISSN 2622-4771

https://jurnal.stie-aas.ac.id/index.php/IJEBAR

results are not optimal. In this entrepreneurial development program, we aim to form an organizational structure so that work can be done together and can serve consumers maximally. We divert the work that was originally done in our room to be done in front of the house so that the business that is being carried out is easily recognized by the surrounding community. From the results of student entrepreneurship development, there are 7 group business groups and 3 independent businesses, namely:

a. SP COMPUTER

SP computer was established in groups consisting of 3 students of class 2017 Informatics Engineering study program. Type of Business SP Computer is a PC, laptop, printer computer service. Besides that, it also sells cellphone accessories, headphones and electronic equipment.

b. DC COMPUTER, Computer Services with a ball pick-up system and also working in consumer places, carried out independently, Information System students' class of 2019.

c. IMAGINATION NOTES Creative Lounge and Coffee, web design services for Computer and Coffee are carried out in groups from Information Systems Students class of 2017.

d. SHIFCOMPUTER PC, laptop and smartphone computer services. Carried out in groups from the Class 2017 Information System Students and 2018 batch.

e. MCHDESIGN, services in the field of multimedia, accepting design orders, processing graduation photos, birthday photos etc. conducted independently, Informatics Engineering students' class of 2018.

f. GAMMACOM PC, laptop and printer computer services. Carried out in groups of Informatics Engineering Students class of 2017.

g. TAJJI, Web Computer Design services are carried out in groups of Information System Students class of 2017

h. SOCIAL MEDIA MARKETING, a digital marketing service that sells followers to help newly opened businesses, the 2016 class of information system students. 
International Journal of Economics, Business and Accounting Research (IJEBAR)

Peer Reviewed - International Journal

Vol-4, Issue-3, 2020 (IJEBAR)

E-ISSN: 2614-1280 P-ISSN 2622-4771

https://jurnal.stie-aas.ac.id/index.php/IJEBAR

\subsection{Activities Documentation}
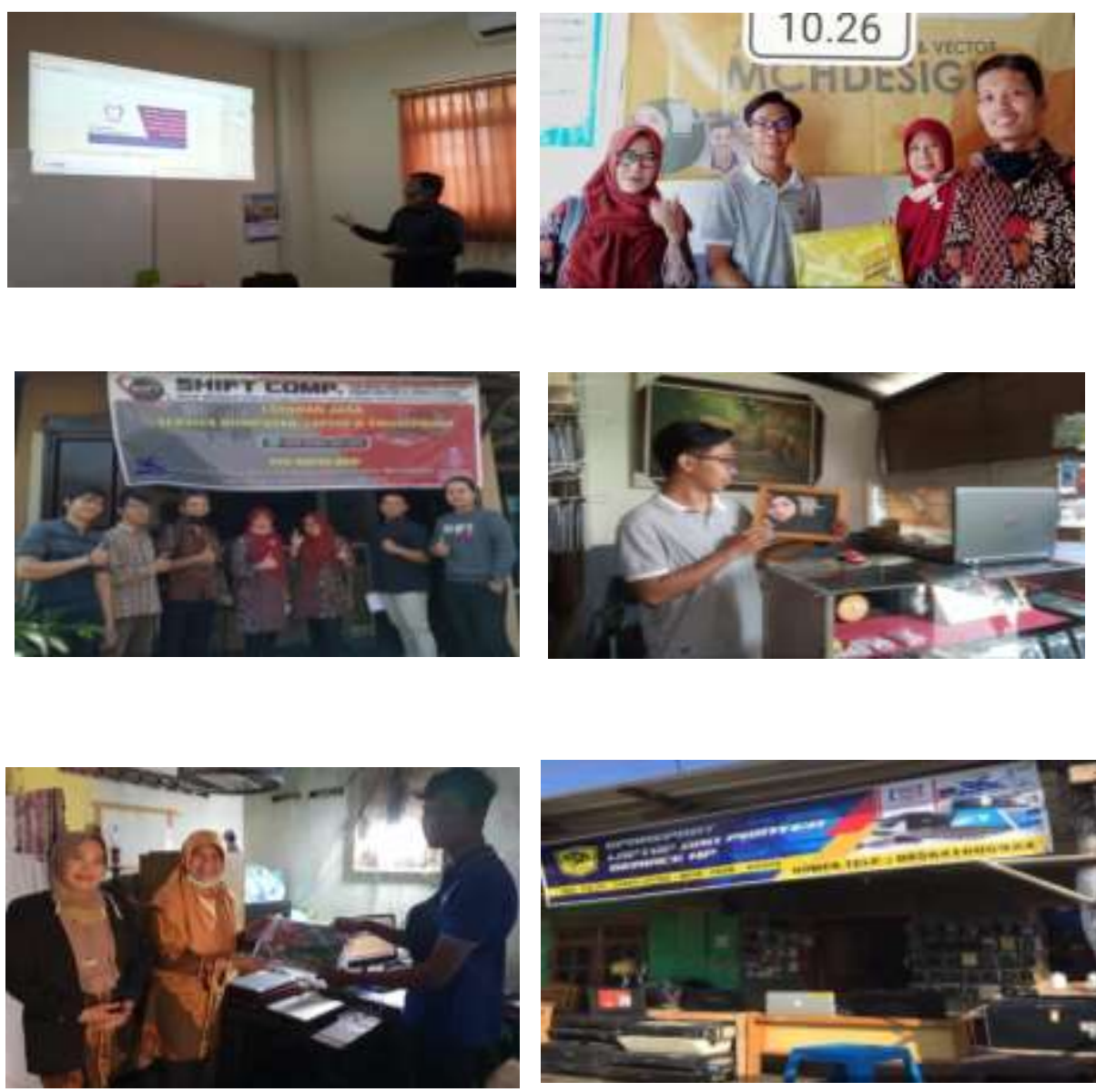

Based on the results of the Entrepreneurship Development Program activities that we have carried out, we have produced 20 tenants of students at Duta Bangsa Surakarta University, consisting of 5 student business groups and 2 student independent businesses. Overall, the implementation of the Community Service for the Student Entrepreneurship Development Program at Duta Bangsa University Surakarta went well.

\section{Acknowledgments}

The team for implementing community service activities for entrepreneurship development programs would like to thank:

- Directorate of Research and Community Service Directorate General of Research and Development Ministry of Research, Technology and Higher Education Deputy of Research and Development Strengthening Ministry of Research and Technology/National Research and Innovation Agency for 2020. (RISTEK BRIN) which has funded this activity.

- Implementing partners of Duta Bangsa University Surakarta entrepreneurship development program that has helped carry out this activity.

- Students who have helped the implementation of this PPK activity.

- All parties who have helped the Student Entrepreneurship Development Program. 
International Journal of Economics, Business and Accounting Research (IJEBAR)

Peer Reviewed - International Journal

Vol-4, Issue-3, 2020 (IJEBAR)

E-ISSN: 2614-1280 P-ISSN 2622-4771

https://jurnal.stie-aas.ac.id/index.php/IJEBAR

References

Purnomo, Lestari „Hastuti.,2016 Aplikasi Komputasi Cerdas Sebagai Konsultan Bisnis Dan Technopreneurship Bidang Teknologi Informasi Untuk Mahasiswa, tahun ke 1 dari rencana 2 tahun . Penelitian Hibah Bersaing Kemenristek Dikti

Purnomo,Lestari,Hastuti, 2017. Expert System Design For Guidance of Information

Technologi Technopreneurships Based on Students Personal Characteristics,

Internasional Journal of Enginering Reseach \& Technology (IJERT), ISSN :

2278-0181, vol.6, Issue 11, November - 2017, Publised by : http://www.ijert.org

Jaharuddin , Purnawan, etc, 2017, Strategi Melahirkan Mahasiswa Pengusaha

Pemula (Studi Kasus Mahasiswa Universitas Muhammadiyah Jakarta) , Jurnal

Kewirausahaan \& Bisnis ISSN : 1979-861X E-ISSN : 2549-1555

Hastuti.utami,2019 Model Pengembangan Kewirausahaan dengan metode PBL,

Laporan penelitian Institusi Universitas Duta Bangsa Surakarta. 